\title{
In situ response of Nostoc commune s.l. colonies to desiccation in Central Svalbard, Norwegian High Arctic
}

\author{
Jana KvíderovÁ ${ }^{1}$ Josef ElsteR ${ }^{1,2} \&$ Miloslav ŠIMEK ${ }^{2,3}$ \\ ${ }^{1}$ Institute of Botany ASCR, Třebon̆, Czech Republic; \\ ${ }^{2}$ University of South Bohemia, Faculty of Science, České Budějovice, Czech Republic \\ ${ }^{3}$ Institute of Soil Biology, Biology Centre AS CR, České Budějovice, Czech Republic \\ e-mails:kviderova@butbn.cas.cz,jelster@butbn.cas.cz,misim@upb.cas.cz
}

\begin{abstract}
The effects of desiccation on photochemical processes and nitrogenase activity were evaluated in Nostoc commune s.l. colonies in situ from a wet thufur meadow at Petuniabukta, Billefjorden, Central Svalbard, during the 2009 arctic summer. The colonies were collected in the fully hydrated state, and were subjected to slow desiccation at ambient temperatures $\left(5-8^{\circ} \mathrm{C}\right)$ and low light $\left(30-80 \mu \mathrm{mol} \cdot \mathrm{m}^{-2} \cdot \mathrm{s}^{-1}\right)$. For each colony the weight, area, photochemical performance, and nitrogenase activity were determined at the beginning, as well as on every day during the first four days of the experiment; thereafter, on every second day until desiccation was complete. The photochemical performance was evaluated from variable chlorophyll fluorescence parameters $\left(\mathrm{F}_{\mathrm{V}} / \mathrm{F}_{\mathrm{M}}, \Phi_{\mathrm{PSII}}, \mathrm{qP}\right.$, and NPQ), and the nitrogenase activity was estimated by an acetylene-ethylene reduction assay. A significant decrease in the photochemically active area was recorded from the third day, when the colony had lost approximately $40 \%$ of its original weight indicating some changes in the extracellular matrix, and stopped on the $14^{\text {th }}$ to $18^{\text {th }}$ day. No effects of the desiccation on the main photochemical parameters $\left(\mathrm{F}_{\mathrm{v}} / \mathrm{F}_{\mathrm{M}}, \Phi_{\mathrm{PSII}}, \mathrm{qP}\right)$ were observed up to the sixth to eighth days of desiccation. Slightly lower values of $\mathrm{F}_{\mathrm{V}} / \mathrm{F}_{\mathrm{M}}$ and $\Phi_{\mathrm{PSII}}$ recorded in fullyhydrated colonies could be caused by impaired diffusion of $\mathrm{CO}_{2}$ into cells. The steep reduction of photochemical activity occurred between the eighth and tenth day of the experiment, when the colony had lost approximately $80 \%$ of its fully-hydrated weight. The nitrogenase activity was highest on the first day, probably due to improved diffusion of $\mathrm{N}_{2}$ into cells, then declined, but was detectable until the sixth day of the experiment. Since Nostoc commune s.l. colonies were capable of photosynthesis and nitrogen fixation to the level of ca. $60 \%$ of its fullyhydrated weight, even partly-hydrated colonies contribute substantially to carbon and nitrogen cycling in the High Arctic wet meadow tundra ecosystem.
\end{abstract}

Key words: Arctic, chlorophyll fluorescence, desiccation, nitrogenase activity, Nostoc commune s.l., Svalbard, wet thufur meadows

\section{Introduction}

The response of cyanobacteria to desiccation is similar to that of other poikilohydric (micro) organisms, i.e. (micro)organisms tolerating desiccation, such as microalgae, lichens, and mosses (Alpert 2000; AlPert 2005). This response similarity indicates that desiccation was one of the major stresses during the early evolution of photosynthetic microorganisms (Роттs 1999). Resistance to desiccation is correlated with other stresses, especially UV radiation, probably due to desiccation-activated protection from oxidative damage (PotTs 1999; Alpert 2000). The mechanisms of cyanobacterial response and tolerance to water loss include a complex network of interactions and processes at various cellular levels and/or compartments. The desiccationresistant species usually develop thick mucilage envelopes or sheaths, or form akinetes. The cells synthesize large amounts of osmoticaly active compounds, e.g. oligosaccharides trehalose and sucrose, chaperones and water stress proteins. To prevent membrane damage due to formation of reactive oxygen species, the oxygen-scavenging enzymes (e.g. superoxiddismutases and catalases) are produced. The cells also modify protein structure, e.g. phosphorylation or disulphide linkage of coenzyme A, and increase the degree of unsaturation in membranes. The DNA protection mechanisms can include genome multiplication as well as repair mechanisms, i.e. photoreactivation, excision repair and postreplication repair (РотTs 1994). 
In Arctic hydro-terrestrial environments, considerable (i.e. visible) amounts of microalgal and cyanobacterial biomass can accumulate over long time periods (VINCENT 2000; Elster 2002). The cyanobacteria play a dual role here. Besides being considerable primary producers, they are able to fix atmospheric nitrogen; thus representing an important source of nitrogen for the other organisms, since nitrogen often limits the primary production in the Arctic (DAVEY \& ROTHERY 1992; Liengen \& Olsen 1997, and references therein). Desiccation stresses represent the most severe infliction in the polar regions (DAVEY 1989), so the cyanobacterial primary production and nitrogen fixation have to follow the moisture and temperature conditions, and water deficiency could slow or inhibit there processes (LIENGEN \& Olsen 1997; VInCENT 2000; Novis et al. 2007).

The cyanobacterial genus Nostoc is a significant nitrogen source in the polar environments (LIENGEN \& Olsen 1997; Vincent 2000); additionally, it is considered to be well adapted to desiccation (Pоттs 1999; Роттs 2000). No DNA damage was observed in dried Nostoc commune colonies after 13 years (SHIRKEY et al. 2003); and a dried Nostoc commune colonies were even successfully revived after 55 (SHIRKeY et al. 2003), 87 (LipMAn 1941), or more than one hundred years (CAMERON 1962). The desiccation leads to the diminution of the physiological processes in an ordered sequence. First the nitrogen fixation ceases, followed by photosynthesis, and finally respiration; upon rehydration, this order is reversed. Increased respiration is recorded several minutes after rehydration, but it takes hours to recover the photosynthetic function, and days to start the nitrogenase activity again (SCHERER et al. 1984; Davey 1989; Scherer \& Zhong 1991; Hawes et al. 1992; Pотts 2000; Qiu \& GaO 2001).

Our experimental locality in Petuniabukta, Billefjorden, Central Svalbard, in the High Norwegian Arctic, is situated in a lowland coastal terrace wet thufur meadow. The meadow is saturated with water at the beginning of the vegetation season, due to extensive snow melt; however, it gradually becomes desiccated during the summer and early fall. The desiccation process can be interrupted by short rain events that can temporally supply the tundra with water again. The tundra vegetation is often subjected to repeated cycles of drying and re-hydration (HodkINSON et al. 1999). The colonies of Nostoc

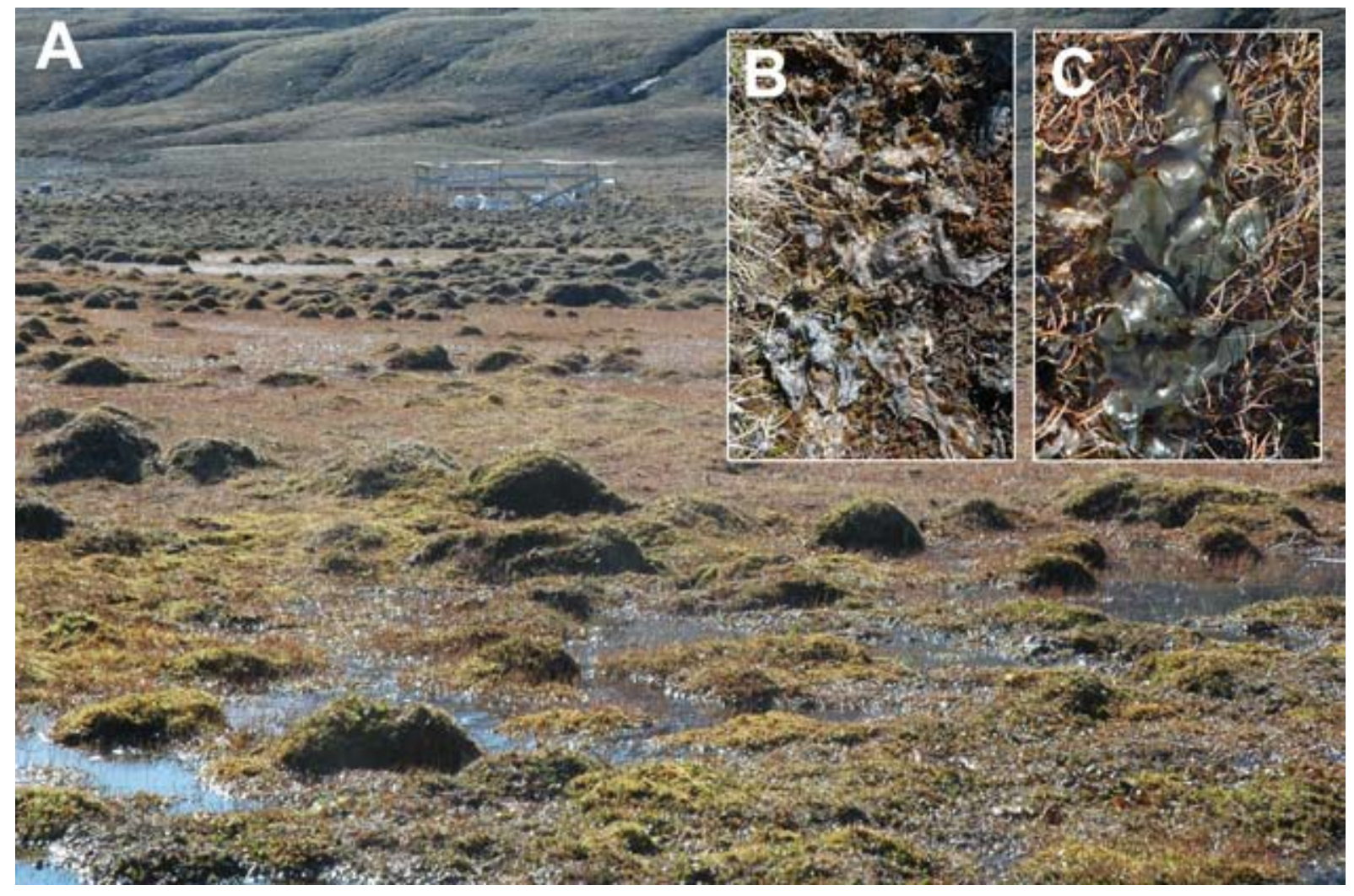

Fig. 1. Thufur tundra (A) in Petuniabukta, Billefjorden, Central Svalbard in 2009; inserted detailed pictures of dry (B) and wet (C) colonies of Nostoc commune s.l. 
commune s.l. are abundant, and produce a visible biomass contributing to the total carbon and nitrogen cycling in this ecosystem (LIENGEN \& Olsen 1997; fig. 1). In order to determine how water availability affects the photochemical performance and nitrogen fixation, the Nostoc commune s.l. colonies were collected and slowly dried at ambient air temperature and low irradiance. Such an experimental protocol was required in order to eliminate the oxidative stress caused by photoinhibition (HIDEg et al. 1994), and thus to record only those changes which were caused by desiccation (QIU et al. 2003). During the experiment, the main objectives were (1) to determine the time when the first desiccation effects can be observed and the time that is necessary to dry the colonies completely, (2) to follow the changes in photochemical processes and nitrogenase activity caused by slow desiccation, and (3) to evaluate the relations between the physiological performance and hydration state of the Nostoc colonies.

\section{Material and methods}

Sample collection. In the 2009 summer season, 20 fully hydrated Nostoc commune s.l. colonies of different weights, ranging from 0.398 to 3.253 $\mathrm{g}$, were collected in several small ponds in a wet thufur meadow at Petuniabukta, Billefjorden, Central Svalbard (N 78 $43^{\prime} 49^{\prime \prime}$ E $16^{\circ} 26^{\prime} 41^{\prime \prime}, 15$ m a.s.l., Fig. 1). The colonies were put into $50 \mathrm{ml}$ plastic tubes with approximately $25 \mathrm{ml}$ of water from the locality, and then transferred in a cooling bag to the station. There, they were weighted and photographed, and their photochemical performance and nitrogen fixation were measured. These measurements were completed within $12 \mathrm{hrs}$ from the colonies having been collected.

Desiccation procedure. After these measurements were taken at the beginning of the field experiment, the colonies were placed on desiccation plates covered by a sheet of cloth and filter paper in a shaded dry place (on the table in front of the field station). The experiment was performed in low light conditions (30$\left.80 \mu \mathrm{mol} \cdot \mathrm{m}^{-2} \cdot \mathrm{s}^{-1}\right)$ and ambient temperatures of $5-8^{\circ} \mathrm{C}$. At the beginning of experiment, the plate was wetted, in order to simulate the natural desiccation processes in the field. The colonies were weighted, photographed, and their photochemical performance and nitrogen fixation were measured every day for the first four days of the experiment; after that, on every second day until desiccation was complete.

Weight and colony area. The individual colonies were weighed with digital scales (MXX-123, Denver Instruments, Germany). The colonies weights were normalized to the full hydrated state at the start of the experiment. The rate of desiccation of individual colonies was estimated from exponential weight decay curve fitting, using SigmaPlot 10.0 software (Systat, USA).

The photochemically active area (PAA) was determined during fluorescence data evaluation (FluorCam 7 software, Photon Systems Instruments, Czech Republic), as the maximum number of pixels where the variable fluorescence signal was detected.

Photochemistry. The photochemical processes were measured using a FluorCam 700MF fluorescence imaging camera (Photon Systems Instruments, Czech Republic). The dark adaptation before the measurement lasted at least $4 \mathrm{hrs}$. The protocol for quenching analysis was used. The red measurement pulses of less than $3 \mu \mathrm{mol} . \mathrm{m}^{-2} \cdot \mathrm{s}^{-1}$ lasted $33.3 \mu \mathrm{s}$. The white saturation pulses of $2100 \mu \mathrm{mol} \cdot \mathrm{m}^{-2} \cdot \mathrm{s}^{-1}$, lasting $800 \mathrm{~ms}$, were applied to define $\mathrm{F}_{\mathrm{M}}$ and $\mathrm{F}_{\mathrm{M}}{ }^{\prime}$. The first saturation pulse in order to determine the maximum quantum yield $\left(\mathrm{F}_{\mathrm{v}} /\right.$ $\mathrm{F}_{\mathrm{M}}$ ) was set $10 \mathrm{~s}$ after the start of measurement, and was followed by $40 \mathrm{~s}$ of dark relaxation. Then, red actinic light of $100 \mu \mathrm{mol} \mathrm{m}{ }^{-2} \mathrm{~s}^{-1}$ was switched on for 2 minutes, and four saturation pulses were applied at 30, 66, 102, and $139 \mathrm{~s}$ after the start of the experiment, in order to determine $\mathrm{F}_{\mathrm{M}}{ }^{\prime}$ during light exposure. The period of actinic light was followed by $10 \mathrm{~s}$ of dark relaxation. The photochemical parameters were calculated by FluorCam 7 software (Photon Systems Instruments, Czech Republic), according to ROHÁČEK \& BARTÁK (1999) and MAXwell \& JohNSON (2000).

The $\mathrm{F}_{\mathrm{v}} / \mathrm{F}_{\mathrm{M}}$, which indicates the maximum possible quantum yield of photosystem II (PSII), was measured in the dark-adapted state, and was calculated according to the equation:

$F_{V} / F_{M}=\frac{F_{M}-F_{0}}{F_{M}}(1)$

where $\mathrm{F}_{0}$ is the minimum fluorescence in the dark, and $\mathrm{F}_{\mathrm{M}}$ is the maximum fluorescence during the saturation pulse.

The actual quantum yield $\left(\Phi_{\mathrm{PSII}}\right)$ reflected the actual photochemical yield in PSII in light, and was calculated as:

$\Phi_{\mathrm{PSII}}=\frac{\mathrm{F}_{\mathrm{M}}{ }^{\prime}-\mathrm{F}_{\mathrm{T}}}{\mathrm{F}_{\mathrm{M}}^{\prime}}(2)$

where $\mathrm{F}_{\mathrm{T}}$ is the steady-state fluorescence, and $\mathrm{F}_{\mathrm{M}}{ }^{\prime}$ is the maximum fluorescence during the saturation pulse during actinic light exposure.

The Stern-Volmer non-photochemical 
quenching (NPQ) is correlated to the amount of energy that is used in non-radiative energy dissipation (RоHÁČEK 2002), and was calculated according to equation:

$$
N P Q=\frac{F_{M}-F_{M}^{\prime}}{F_{M}^{\prime}}(3) .
$$

The photochemical quenching $(\mathrm{qP})$ is that proportion of the PSII reaction centers that are able to accept a photon (so-called open reaction centers), which is calculated as:

$q \mathrm{P}=\frac{\mathrm{F}_{\mathrm{M}}{ }^{\prime}-\mathrm{F}_{\mathrm{T}}}{\mathrm{F}_{\mathrm{M}}{ }^{\prime}-\mathrm{F}_{0}{ }^{\prime}}(4)$,

where $\mathrm{F}_{0}{ }^{\prime}$ is the minimum fluorescence within one second after actinic light exposure.

Nitrogenase activity. The nitrogenase activity was measured by an acetylene-ethylene reduction assay (STEWART et al. 1967). First, $5 \mathrm{ml}$ of commercial-grade acetylene was added by syringe to $100 \mathrm{ml}$ glass flasks containing cyanobacterial colonies and closed with butyl rubber stoppers. The assay was performed under the same conditions as the desiccation experiment. The headspace samples of $5 \mathrm{ml}$ were collected by a syringe and transferred into $5 \mathrm{ml}$ evacuated LABCO vials after 30 and $90 \mathrm{~min}$ of incubation. Ethylene in the headspace samples was quantified with a Hewlett Packard 5890 gas chromatograph (Hewlett Packard, USA) equipped with a flame ionization detector. Nitrogenase activity was expressed in $\mathrm{nmol} \mathrm{C}_{2} \mathrm{H}_{4} \mathrm{~g}^{-1}$ fresh biomass $\mathrm{h}^{-1}$.

Statistical analyses. The statistical analyses were performed by Statistica 8.0 software (StatSoft, U.S.A.), and the results were considered significant if $\mathrm{p}$ was less than 0.05 . Correlation analysis was performed to find possible relationships between the colony weight and the other studied parameters. The Tukey HSD test was used to distinguish the beginning of the desiccation effects, and to determine its final stages. The relationships between the studied parameters and the hydration state were evaluated by linear regression and nonlinear estimation approaches using the least square method, and their fitness were tested by ANOVA.

\section{Results}

Since the fully-hydrated colonies were randomly sampled, their initial values of all measured parameters reflected their variability in situ (Table 1). The measured data during the desiccation were re-calculated as a percentage of the initial

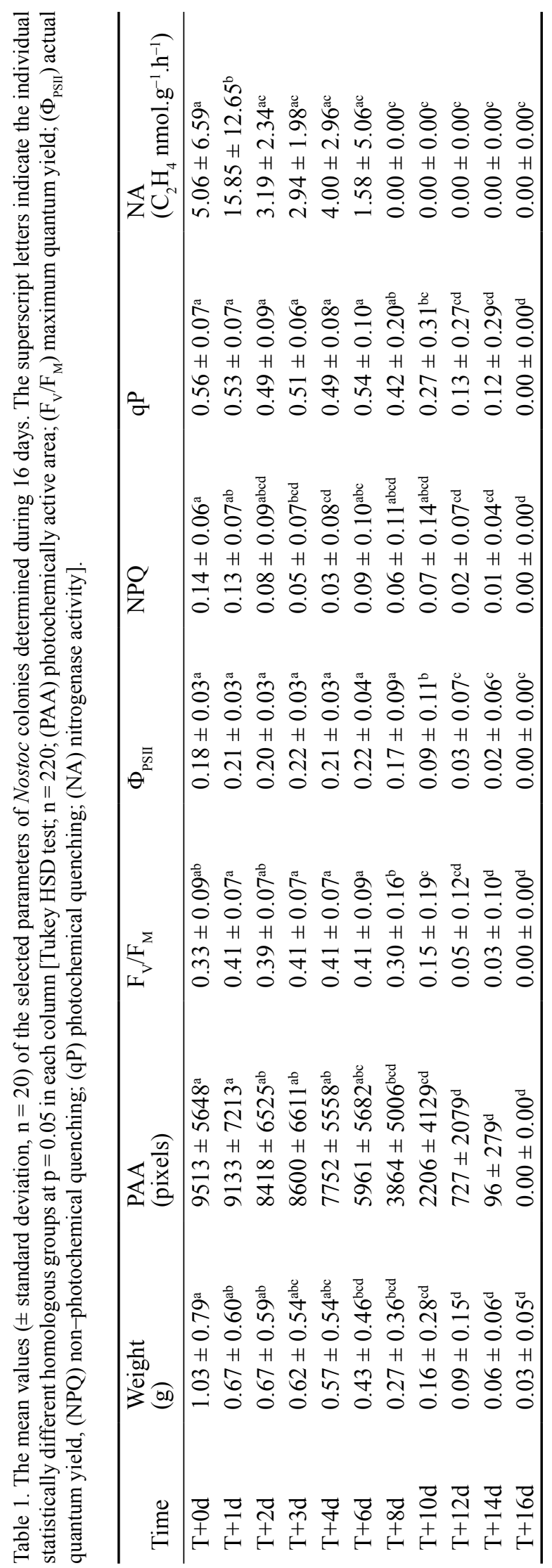


Table 2. The correlation coefficients between colony weight and the selected parameters in fully-hydrated colonies $(n=20)$. Significant coefficient is in bold (for parameter description, see legend to Table 1).

\begin{tabular}{lllllll}
\hline & $\begin{array}{l}\text { PAA } \\
\text { (pixels) }\end{array}$ & $\mathrm{F}_{\mathrm{v}} / \mathrm{F}_{\mathrm{M}}$ & $\Phi_{\text {PSII }}$ & $\mathrm{NPQ}$ & $\mathrm{qP}$ & $\begin{array}{l}\mathrm{NA} \\
\left(\mathrm{C}_{2} \mathrm{H}_{4} \mathrm{~mol}_{\mathrm{g}} \mathrm{g}^{-1} \cdot \mathrm{h}^{-1}\right)\end{array}$ \\
\hline \multirow{2}{*}{ Weight $(\mathrm{g})$} & $\begin{array}{lllll}\mathbf{r}=\mathbf{0 . 9 0 0} \\
p<0.001\end{array}$ & $\mathrm{r}=-0.255$ & $\mathrm{r}=0.245$ & $\mathrm{r}=0.093$ & $\mathrm{r}=0.101$ & $\mathrm{r}=-0.198$ \\
& $p=0.278$ & $p=0.298$ & $p=0.696$ & $p=0.673$ & $p=0.403$ \\
\hline
\end{tabular}

values. This led to slight shifts ( \pm one day) in the estimations of the time when the desiccation effects had been observed for the first time, i.e. statistically significant change of given measured parameter, as well as the time when the complete desiccation, i.e. no further significant weight changes, had occurred (Table 1, Fig. 2).

\section{Weight and colony area}

The colony area and weight were strongly positively correlated in fully-hydrated colonies; however, no significant correlations were found between the colony weight and photochemical parameters or nitrogenase activity in the fullyhydrated colonies (Table 2). Changes of the photochemical parameters and/or nitrogenase activity reflected the physiological states of the colonies, and were independent of their initial weight and area colony area. The weight of the colony gradually decreased during desiccation and statistically significant dehydration was observed after one day. The weight loss continued up to the $16^{\text {th }}$ through $18^{\text {th }}$ day of desiccation (Figure 2 ). The desiccation rates, estimated from the exponentional weight decay curves, were higher in smaller colonies (correlation analysis: $\mathrm{n}=20, \mathrm{r}$ $=0.466, \mathrm{p}=0.038$; non - parametic Kruskal-Wallis ANOVA: $\mathrm{H}=6.52, \mathrm{p}=0.038$, Figure 3 ).

A gradual decrease was also observed in the photochemically active area (PAA); since the colony area, expressed in pixels, was directly proportional to the weight $[\mathrm{g}](\mathrm{n}=220, \mathrm{r}=0.894$, $\mathrm{p}<0.001$ ). A significant reduction in the PAA was recorded on the third day, corresponding to $58.5 \pm 12.1 \%$ of the weight in the original fullyhydrated state. The PAA disappeared by the $14^{\text {th }}$ to $18^{\text {th }}$ day of exposure to desiccation (Fig. 2). A rapid decrease in the colony area started when the colony had lost approximately $40 \%$ of its original weight (Table 3, Fig. 4).

\section{Photochemistry}

Contrary to the weight and PAA, the values of the photochemical parameters were stable up to the sixth $\left(\mathrm{F}_{\mathrm{v}} / \mathrm{F}_{\mathrm{M}}\right)$, eighth $\left(\Phi_{\mathrm{PSII}}, \mathrm{qP}\right)$, and even tenth (NPQ) days of desiccation corresponding to $36.8 \pm 12.7,21.1 \pm 11.1$, and $11.4 \pm 9.1 \%$ (mean \pm standard deviation; $\mathrm{n}=20$ ) of the initial weight, respectively. These photochemical parameters indicated the relatively good physiological state of the colonies. The slight increases of ca. $10-$ $30 \%$ for $\mathrm{F}_{\mathrm{V}} / \mathrm{F}_{\mathrm{M}}$ and $\Phi_{\text {PSII }}$ against their initial values suggested a slight stress in fully-hydrated colonies (Figs 2, 4). The steep reduction of photochemical activity occurred between the eighth and tenth days of the experiment, and no photochemical activity was observed after the twelfth day when the $\mathrm{F}_{\mathrm{v}} / \mathrm{F}_{\mathrm{M}}$ had dropped below 0.1 (Table 2, Fig. 2).

The photochemical activity started to decrease when the colony lost approximately $80 \%$ of its fully-hydrated weight (Table 3, Fig. 4). When the value of the studied parameter dropped to half of what it was in the initial fully hydrated state level, the hydration status was estimated from a nonlinear estimation of a 4-parameter hyperbolic function. A $50 \%$ reduction of the photochemical parameters occurred at $14.1 \%$ for $\mathrm{F}_{\mathrm{V}} / \mathrm{F}_{\mathrm{M}}(\mathrm{n}=220$, $\mathrm{F}=463.4, \mathrm{p}<0.001)$, at $13.2 \%$ for $\Phi_{\mathrm{PSII}}(\mathrm{n}=220$, $\mathrm{F}=513.5, \mathrm{p}<0.001)$, and at $11.0 \%$ for $\mathrm{qP}(\mathrm{n}=$ $220, \mathrm{~F}=327.8, \mathrm{p}<0.001)$ of the initial weight, respecively. For NPQ, no trend was observed; this probably due to photoacclimation processes to lower irradiance during the experiment and the variability of the NPQ in the colonies (Table 3 ).

\section{Nitrogenase activity}

The nitrogenase activity rose significantly after one day of desiccation; however, this steep increase was followed in the following days by a slower decline to values comparable to the initial stage (Table 1, Fig. 2). The nitrogenase activity was detectable up to $6^{\text {th }}$ day of the experiment, but was not observed on the $8^{\text {th }}$; corresponding to an average of $21.1 \pm 11.1 \%$ of original weight in the fully-hydrated state. 

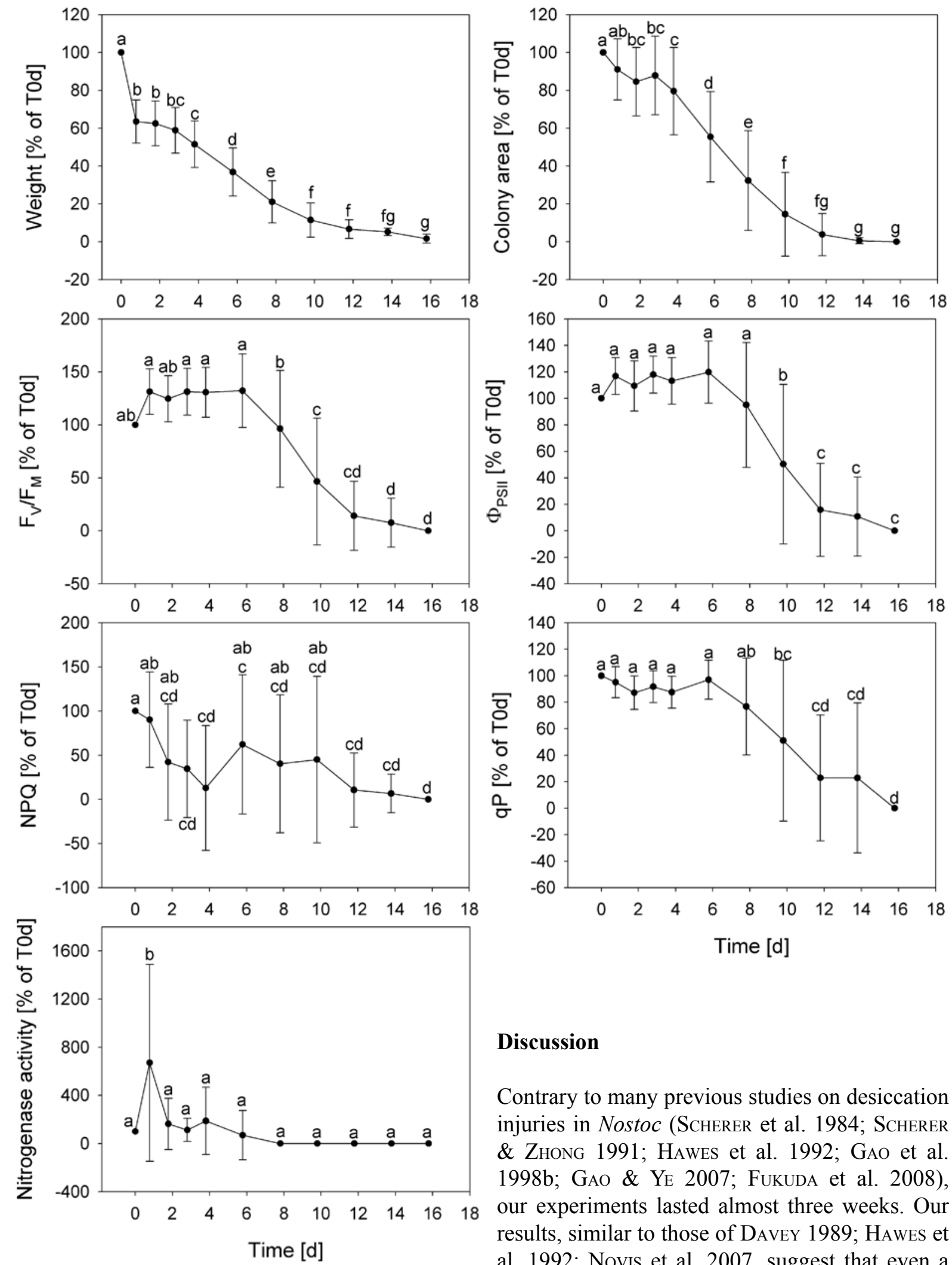

\section{Discussion}

Contrary to many previous studies on desiccation injuries in Nostoc (SCHERER et al. 1984; SCHERER \& ZHONG 1991; Hawes et al. 1992; GAO et al. 1998b; Gao \& Ye 2007; FuKuda et al. 2008), our experiments lasted almost three weeks. Our results, similar to those of DAVEY 1989; HAWES et al. 1992; Novis et al. 2007, suggest that even a partially hydrated Nostoc commune s.l. colony is capable of photosynthesis and nitrogen fixation in

Fig. 2. The time course of the studied parameters (mean \pm standard deviation, $\mathrm{n}=20$ ) during desiccation. The letters above the error bar indicate individual statistically significant different groups (Tukey HSD test, $\mathrm{p}=0.05, \mathrm{n}=220$; for parameter description, see legend to Table 1). for almost two weeks. This could provide a great advantage for the Nostoc commune s.l. itself, and also for the ecological functioning of the thufur meadows where the water supply fluctuates 


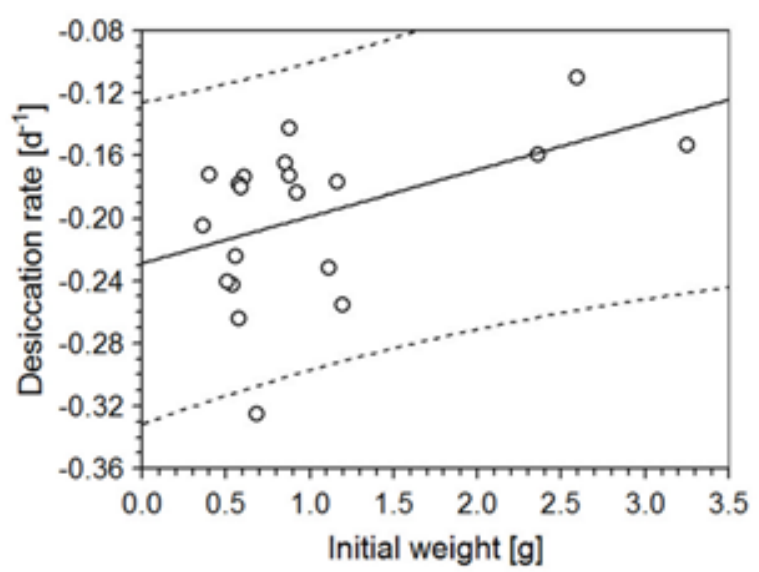

Fig. 3. Dependence of the desiccation rate, estimated from exponentional decay of the colony weight, upon the initial colony weight. Circles - measured values, straight line regression line, dashed line -0.95 prediction interval.

widely (HoDKINSON et al. 1999), so the ability of photosynthesis and nitrogen fixation in partly hydrated state extends the period of favorable growth conditions or helps to survive the less favorable ones.

Slow desiccation, which was performed in our in situ experiments, reflects the actual situation in the tundra where the Nostoc commune s.l. colonies occur on a wet, mostly moss surface which slows down the desiccation rate. Our results also confirmed previously presented data (GAO \& Ai 2004), that smaller colonies lost their water faster than the larger ones, due to their higher surface/volume ratios. Although higher photosynthesis rates can be expected in smaller colonies such as in Nostoc sphaeroides (GAO \& AI 2004; LI \& GAO 2004), no credibly higher photochemical parameters $\left(\mathrm{F}_{\mathrm{v}} / \mathrm{F}_{\mathrm{M}}, \Phi_{\mathrm{PSII}}, \mathrm{qP}\right.$ and NPQ) were observed in our experiments. In the field, the largest colonies could be metabolically active through relatively long dry periods.

The sequence of diminishing of Nostoc commune s.l. metabolic activity was the same as in previous studies, although the fluorescence techniques did not allow respiration measurements (Scherer et al. 1984; Davey 1989; Scherer \& Zhong 1991; Hawes et al. 1992; Ротts 2000; QIU \& GAO 2001). If a colony's water loss was less than ca. $40 \%$ of its fully-hydrated weight, no (or only minor) desiccation damages were observed. At the beginning of desiccation, even the slight increases (ca 30\%) of selected photochemical parameters $\left(\mathrm{F}_{\mathrm{V}} / \mathrm{F}_{\mathrm{M}}\right.$ and $\left.\Phi_{\mathrm{PSII}}\right)$ were recorded indicating improved photochemical performance of partly desiccated colonies. This is probably due to inferior $\mathrm{CO}_{2}$ diffusion to fullyhydrated colonies, or due to possible previous photoinhibition of the colonies in the field. This phenomenon was confirmed by the steep rise in the nitrogenase activity during the initial steps of desiccation. Decreases to $40 \%$ in water content, caused by water loss in the extracellular mucilage, do not influence the photochemical and nitrogenase activities of Nostoc commune s.l. colonies. However, when the weight loss exceeded ca. $40 \%$, the colony started to shrink, and changes in the mucilage structure began as seen from decline of the colony size. The nitrogenase activity declined slowly when the water loss exceeded $70 \%$ and diminished completely at a weight loss of ca. $80 \%$. The photochemical activity remained unaffected until the colonies lost ca. $80 \%$ of their original weight, and was detectable until a weight loss of ca. $90 \%$. The long-term stability of the photochemical performance and nitrogenase activity can be explained by a complex response to water deficiency. At the beginning of the desiccation, the major water loss occurred in the mucilaginous envelopes of the colonies and the intracellular water content was not affected. When the water stress attains a particular limit, modifications of the cytosol and intracellular protective mechanisms are induced (compatible solute synthesis, stabilization of proteins, etc.) (Potts 1999, Tamaru et al. 2005).

Our fluorescence measurements showed that the collected Nostoc commune s.l. colonies were still in a relatively good physiological state up to a water content of ca. $60 \%$ of their original weight; this is in agreement with other publications on Nostoc (GAO et al. 1998a; HIRAI et al. 2004). Similar results were also observed in Nostoc flagelliforme (GAO et al. 1998b; QIU \& GAO 2001), as well as in the cyanobacterial genus Phormidium and green alga Prasiola (DAVEY 1989). The slight depression of photosynthesis in fully-hydrated thalli, observed as lower values of the maximum quantum yield $\left(\mathrm{F}_{\mathrm{v}} / \mathrm{F}_{\mathrm{M}}\right)$, actual quantum yield $\left(\Phi_{\mathrm{PSII}}\right)$, and photochemical quenching (qP) of the colonies, was also observed in the genus Phormidium (Davey 1989). This was probably caused by the limited diffusion of $\mathrm{CO}_{2}$ to the cells, as has also been observed in lichens (Lange \& Green 1996). Minor photoinhibition, encountered in situ before collection, cannot be excluded (CAMPBELL et al. 1998).

The rapid increase of the nitrogenase activity after one day of desiccation could be 

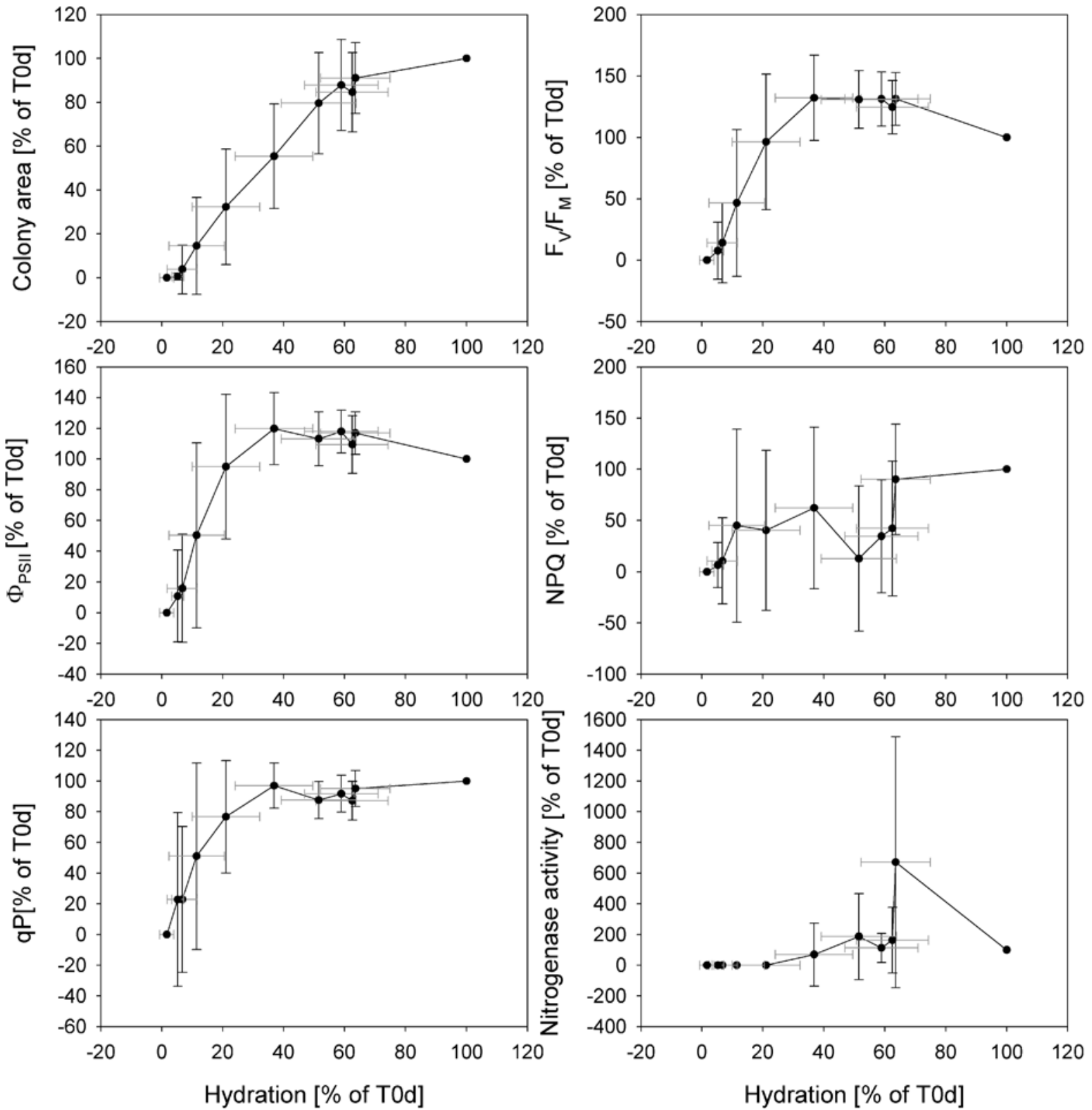

Fig. 4. The relationship between the hydration state and other parameters (mean \pm standard deviation, $\mathrm{n}=20$ ). Horizontal gray bar - the hydration state (mean \pm standard deviation, $\mathrm{n}=20$ ) calculated for each day (for parameter description, see legend to Table 1).

caused by the improved substrate (i.e. acetylene) supply to the enzyme; thus supporting the hypothesis of reduced photosynthesis due to $\mathrm{CO}_{2}$ deficiency in fully-hydrated colonies. The nitrogenase activity ceased at the time when the photochemical parameters started to decline on the sixth day of desiccation. Since the nitrogen fixation is energetically costly (16 ATP per each $\mathrm{N}_{2}$ assimilated; FALKOWSKI \& RAVEN 2007), even a small decline in the cellular energy inputs from photosynthesis and/or respiration should lead to reduction of the nitrogenase activity. However, our methods do not allow measurements of direct primary productivity, nor growth rate measurements, both necessary for an estimation of the carbon and nitrogen balances. There are studies of these relationships and interactions among various photosynthesis measurement methods and nitrogen fixation (e.g. GENTY et al. 1989; SEATON \& WALKer 1990; ROMERo et al. 1992); however, the great variability in the measured data and experimental organisms realistically excludes any estimates that would allow reliable predictions for the Nostoc sp. community. Since the growth rate of cyanobacteria is relatively low in polar ecosystems (VINCENT 2000), long-term laboratory and in situ 
growth experiments are necessary in order to estimate the growth rate/primary production of the Nostoc commune s.l. colonies under different temperature/light regimes in thufur wet meadow Arctic habitats.

The photochemical and nitrogenase activity data obtained during desiccation indicate that even loss of $50 \%$ water did not affect the studied metabolic processes of the Nostoc commune s.l. colonies and the slight colony dehydration (ca 30\% of weight loss) could be even beneficial due to better diffusion of carbon dioxide and nitrogen into the cells. Due to water fluctuation, partial desiccation could be probably the prevailing condition at the Arctic tundra (Hodkinson et al. 1999). Further, the moss substrate (Fig. 1) could reduce the desiccation rate in situ and provide the water to the colonies, extending thus period of Nostoc metabolic activity in the Arctic summer. Our field observation revealed that the water availability in the experimental locality in Petuniabukta could change within several days dramatically, so the tolerance of approximately two-week period of desiccation stress caused by slow drying could reflect common conditions. Due to low growth rate of cyanobacteria in the polar regions, any adaptation that can extend their growth period, even for several days, should be important for not only for their own survival, but also for nitrogen and carbon cycling in harsh environment, and even for ecosystem stabilization (VINCENT 2000). Thus, the ability of photosynthesis and nitrogen fixation of partly-hydrated colonies of Nostoc commune s.l. contribute substantially to carbon and nitrogen economy in the High Arctic wet meadow tundra ecosystem.

\section{Acknowledgements}

This work was supported by institutional long-term research plan AV0Z60050516, the Grant Agency of the Ministry of Education of the Czech Republic (INGO LA341, KONTAKT ME934, and LC06066), and the Grant Agency of the Academy of Sciences of Czech Republic (IAA600660605). We are very grateful to Jana Šnokhousová for her technical assistance, and to the entire group of the III ${ }^{\text {rd }}$ Arctic Research Expedition of the Faculty of Science, University of South Bohemia in České Budějovice for their assistance and friendship. Veronika Šlajchrtová and Linda Jíšová are thanked for their selected laboratory analyses.

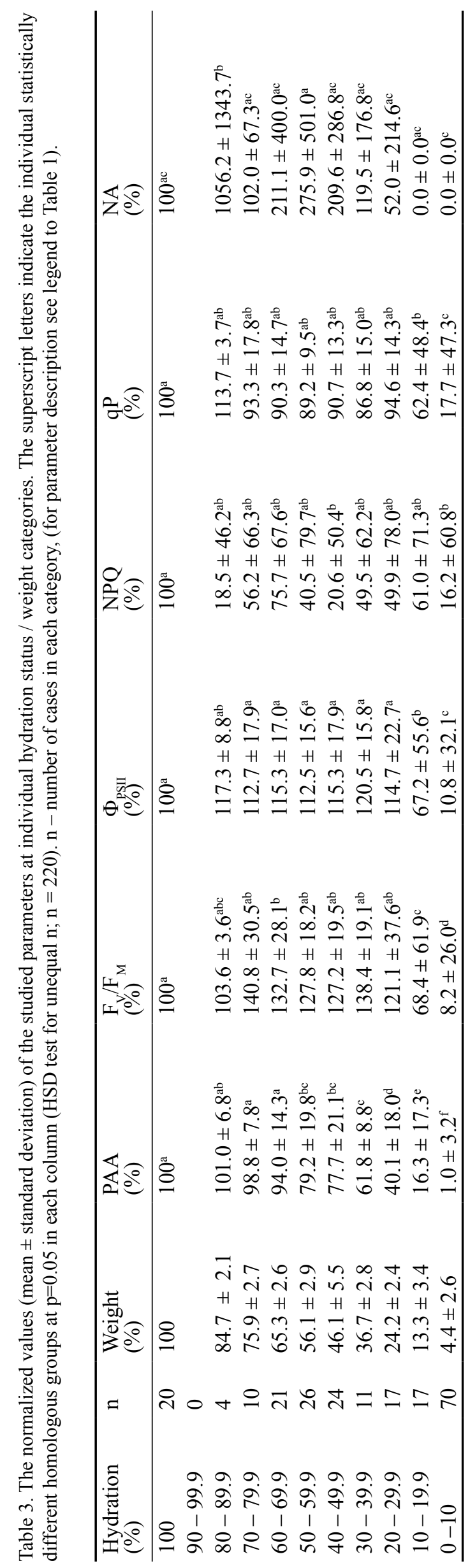




\section{References}

Alpert, P. (2000): The discovery, scope, and puzzle of desiccation tolerance in plants. - Plant Ecology 151: 5-17.

Alpert, P. (2005): The limits and frontiers of desiccation-tolerant life. - Integrative \& Comparative Biology 45: 685-695.

Cameron, R.E. (1962): Species of Nostoc Vaucher occurring in the Sonoran Desert in Arizona. Transactions of the American Microscopical Society $81: 379-384$.

Campbell, D., Hurry, V., Clarke, A. K., Gustafsson, P. \& ÖQuist, G. (1998): Chlorophyll fluorescence analysis in cyanobacterial photosynthesis and acclimation. - Microbiology and Molecular Biology Reviews 62: 667-683.

Davey, M.C. (1989): The effects of freezing and desiccation on photosynthesis and survival of terrestrial Antarctic algae and cyanobacteria. Polar Biology 10: 29-36.

Davey, M.C. \& Rothery, P. (1992): Factors causing the limitation of growth of terrestrial algae in maritime Antarctica during late summer. - Polar Biology 12: 595-601.

ELSTER, J. (2002): Ecological classification of terrestrial algal communities in polar environments. - In: Beyer, L. \& Bötler, M. (eds): Geoecology of Antarctic ice-free coastal lanscapes. - pp. 303326, Springer-Verlag, Berlin Heidelberg.

Falkowski, P. \& Raven, J. A. (2007): Aquatic photosynthesis - 484 pp., Princeton University Press, Princeton.

Fukuda, S.-Y., Yamakawa, R., Hirai, M., Kashino, Y., KoIKe, H. \& SAtoH, K. (2008): Mechanisms to avoid photoinhibition in a desiccation-tolerant cyanobacterium, Nostoc commune. - Plant and Cell Physiology 49: 488-492.

GAO, K. \& Ai, H. (2004): Relationship of growth and photosynthesis with colony size in am edible cyanobacterium, Ge-Xian-Mi Nostoc (Cyanophyceae). - Journal of Phycology 40: 523-526.

GaO, K., Qiu, B., XIA, J. \& Yu, A. (1998a): Light dependency of the photosynthetic recovery of Nostoc flagelliforme. - Journal of Applied Phycology 10: 51-53.

GAO, K., QIU, B., XIA, J., YU, A. \& Li, Y. (1998b): Effect of wind speed on loss of water from Nostoc flagelliforme colonies. - Journal of Applied Phycology 10: 55-58.

GAO, K. \& Ye, C. (2007): Photosynthetic insensivity of the terrestrial cyanobacterium Nostoc flagelliforme to solar UV radiation while rehydrated or desiccated. - Journal of Phycology 43: 628-635.

Genty, B., Briantias, J.-M. \& BaKer, N.R. (1989): The relationship between the quantum yield of photosynthetic electron transport and quenching of chlorophyll fluorescence. - Biochimica et Biophysica Acta 990: 87-92.

Hawes, I., Howard-Williams, C. \& Vincent, W. (1992): Desiccation and recovery of antarctic cyanobacterial mats. - Polar Biology 12: 587594.

Hideg, E., Spetea, C. \& Vass, I. (1994): Singlet oxygen production in thylakoid membranes during photoinhibition as detected by EPR spectroscopy. - Photosynthesis Research 39: 191-199.

Hirai, M., Yamakawa, R., Nishio, J., Yamaji, T., Kashino, Y., Koike, H. \& Satoh, K. (2004): Deactivation of photosynthetic activities is triggered by loss of a small amount of water in a desiccation-tolerant cyanobacterium, Nostoc commune. - Plant and Cell Physiology 45: $872-878$.

Hodkinson, I.D., Webb, N.R., Bale, J.S. \& Block, W. (1999): Hydrology, water availability and tundra ecosystem function in a changing climate: the need for a closer integration of ideas? - Global Change Biology 5: 359-369.

Lange, O.L. \& Green, T.G.A. (1996): High thallus water content severely limits photosynthetic carbon gain of Central European epilithic lichens under natural conditions. - Oecologia 108: 13-20.

LI, Y. \& GAO, K. (2004): Photosynthetic physiology and growth as a function of colony size in the cyanobacterium Nostoc sphaeroides. European Journal of Phycology 39: 9-15.

Liengen, T. \& Olsen, R.A. (1997): Nitrogen fixation by free-living cyanobacteria from different coastal sites in a High Arctic tundra, Spitzbergen. Arctic and Alpine Research 29: 470-477.

Lipman, C.B. (1941): The successful revival of Nostoc commune from a herbarium specimen eighty-seven years old. - Bulletin of the Torrey Botanical Club 68: 664-666.

Maxwell, K. \& Johnson, G.N. (2000): Chlorophyll fluorescence - a practical guide. - Journal of Experimental Botany 51: 659-668.

Novis, P.M., Whitehead, D., Gregorich, E.G., Hunt, J.E., Sparrow, A.D., Hopkins, D.W., Elberling, B. \& GreENFIELD, L.G. (2007): Annual terrestrial fixation in terrestreial populations of Nostoc commune (Cyanobacteria) from an Antarctic dry valley is driven by temperature. - Global Change Biology 13: 1224-1237.

Potтs, M. (1994): Desiccation tolerance of prokaryotes. - Microbiological Reviews 58: 755-805.

Pоттs, M. (1999): Mechanisms of desiccation tolerance in cyanobacteria. - European Journal of Phycology 34: 319-328.

Potts, M. (2000): Nostoc. - In: Whitton, B.A. \& PotTs, M. (eds): The ecology of cyanobacteria. 
- pp. 465-504, Kluwer Academic Publishers, Dordrecht.

QIU, B. \& GAO, K. (2001): Photosynthetic characteristics of the terrestrial blue-green alga, Nostoc flagelliforme. - European Journal of Phycology 36: 147-156.

Qiu, B., Zhang, A. \& LiU, Z. (2003): Oxidative stress in Nostoc flagelliforme subjected to desiccation and effects of exogenous oxidants on its photosynthetic recovery. - Journal of Applied Phycology 15: 445-450.

ROHÁČEK, K. (2002): Chlorophyll fluorescence parameters: the definitions, photosynthetic meaning and mutual relationship. Photosynthetica 40: 13-29.

ROHÁČEK, K. \& BARTÁK, M. (1999): Technique of the modulated chlorophyll fluorescence: basic concepts, useful parameters, and some applications. - Photosynthetica 37: 339-363.

Romero, J.M., LARA, C. \& SivaK, M.N. (1992): Effect of carbon and nitrogen assimilation on chlorophyll fluorescence emission by cyanobycterium Anacystis nidulans. - Physiologia Plantarum 85: 433-438.

Seaton, G.G.R. \& Walker, D.A. (1990): Chlorophyll fluorescence as a measure of photosynthetic carbon assimilation. - Proceedings of the Royal Society B: Biological Sciences 242: 29-35.

Shirkey, B., McMaster, N.J., Smith, S.C., Wright, D.J., Rodriguez, H., Jaruga, P., Birincioglu, M., Helm, R.F. \& Potts, M. (2003): Genomic DNA of Nostoc commune (Cyanobacteria) becomes covalently modified during long-term (decades) desiccation but is protected from oxidative damage and degradation. - Nucleic Acids Research 31: 2995-3005.
Scherer, S., Ernst, A., Chen, T.-W. \& Böger, P. (1984): Rewetting of drought-resistant bluegreen algae: time course of water uptake and reappearance of respiration, photosynthesis, and nitrogen fixation. - Oecologia 62: 418-423.

Scherer, S. \& Zhong, Z.-P. (1991): Desiccation independence of terrestrial Nostoc commune ecotypes (Cyanobacteria). - Microbial Ecology 22: 271-283.

Stewart, W.D.P., Fitzgerald, G.P. \& Burris, R.H. (1967): In situ studies of $\mathrm{N}_{2}$ fixation using the acetylene reduction technique. - Proceedings of the National Academy of Sciences of the United States of America 58: 2071-2073.

TAmaru, Y., TAKani, Y., Yoshida, T. \& SAKamoto, T. (2005): Crucial role of extracellular polysaccharides in desiccation and freezing tolerance in the terrestrial cyanobacterium Nostoc commune. - Applied and Environmental Microbiology 71: 7327-7333.

VINCENT, W.F. (2000): Cyanobacterial dominance in the Polar Regios. - In: Whitton, B. A. \& Potts, M. (eds): The ecology of cyanobacteria. - pp. 321340, Kluwer Academic Publishers, Dordrecht.

(C) Czech Phycological Society (2011)

Recieved Sept 2010

Accepted Dec 2010 